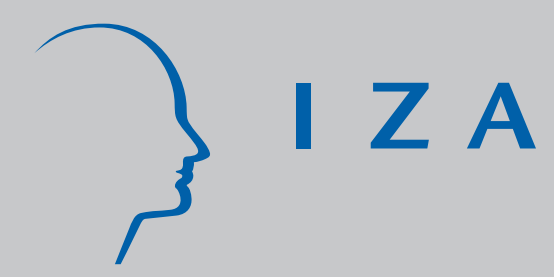

IZA DP No. 243

Economic Reform and Mortality in the Former Soviet Union:

A Study of the Suicide Epidemic in the 1990s

Elizabeth Brainerd

J anuary 2001 


\title{
Economic Reform and Mortality in the Former Soviet Union: A Study of the Suicide Epidemic in the 1990s
}

\author{
Elizabeth Brainerd \\ Williams College and Center for International Development, \\ Harvard University and IZA, Bonn
}

Discussion Paper No. 243

January 2001

IZA

P.O. Box 7240

D-53072 Bonn

Germany

Tel.: +49-228-3894-0

Fax: +49-228-3894-210

Email: iza@iza.org

This Discussion Paper is issued within the framework of IZA's research area Labor Markets in Transition. Any opinions expressed here are those of the author(s) and not those of the institute. Research disseminated by IZA may include views on policy, but the institute itself takes no institutional policy positions.

The Institute for the Study of Labor (IZA) in Bonn is a local and virtual international research center and a place of communication between science, politics and business. IZA is an independent, nonprofit limited liability company (Gesellschaft mit beschränkter Haftung) supported by the Deutsche Post AG. The center is associated with the University of Bonn and offers a stimulating research environment through its research networks, research support, and visitors and doctoral programs. IZA engages in (i) original and internationally competitive research in all fields of labor economics, (ii) development of policy concepts, and (iii) dissemination of research results and concepts to the interested public. The current research program deals with (1) mobility and flexibility of labor markets, (2) internationalization of labor markets and European integration, (3) the welfare state and labor markets, (4) labor markets in transition, (5) the future of work, (6) project evaluation and (7) general labor economics.

IZA Discussion Papers often represent preliminary work and are circulated to encourage discussion. Citation of such a paper should account for its provisional character. 
IZA Discussion Paper No. 243

January 2001

\title{
ABSTRACT \\ Economic Reform and Mortality in the Former Soviet Union: A Study of the Suicide Epidemic in the 1990s
}

Male suicide rates in Russia, Belarus, Ukraine and the Baltic countries increased substantially in the early 1990s and are now the highest in the world. To what extent is this suicide epidemic explained by the macroeconomic instability experienced by these countries in that period? Fixed effects regressions across 22 transition economies indicate that male suicide rates are highly sensitive to the state of the macroeconomy, suggesting that the steep and prolonged declines in GDP in the western countries of the former Soviet Union may have been partly to blame for the suicide epidemic. Evidence also indicates that the general adult male mortality crisis in the region had a 'feedback' effect on suicide rates, with the loss of a spouse or friend - or declining life expectancy itself - contributing to rising suicide rates. Female suicide rates, in contrast, are insensitive to the state of the macroeconomy and are more strongly related to alcohol consumption.

JEL Classification: $\quad$ I12, P20

Keywords: Suicide; mortality; transition economies

\author{
Elizabeth Brainerd \\ Department of Economics \\ Williams College \\ Williamstown, MA 0126779 \\ USA \\ Tel.: +1413 5972476 \\ Fax: +14135974045 \\ Email: Elizabeth.Brainerd@williams.edu
}




\section{INTRODUCTION}

The unprecedented increase in mortality rates in Russia in the 1990s has drawn much attention from researchers, and deservedly so. The numbers are shocking: between 1990 and 1994 the death rate among working age men in Russia increased by 74 percent, from 759.2 to 1323.7 deaths per 100,000 population; this translated into a decline in male life expectancy at birth from 63.8 years to 57.6 years. Perhaps less well-known is that many countries of the former Soviet Union - in particular, Belarus, Ukraine, and the three Baltic countries - experienced a similar increase in mortality rates over the same period. Indeed, it is not an exaggeration to describe the western region of the former Soviet Union, starting from Estonia in the north and ending with Ukraine in the south, as a mortality belt.

At the same time, the countries which directly border this 'mortality belt' and which also experienced a severe economic shock in the 1990s - Poland, the Czech and Slovak Republics, Hungary, and Romania - recorded little or no increase in mortality rates during their transition from communism, and since the mid-1990s many of these countries enjoyed the fastest increases in life expectancy recorded in their recent history.

Why did demographic catastrophe afflict some countries but not others during the transition from communism? Are the differences across countries explained simply by varying success in economic reform? To begin to solve these puzzles, one can exploit differences in mortality rates by cause across countries, since some causes of death are more sensitive to cyclical changes in the economy than others. For example, deaths due to cancer are unlikely to be influenced by the state of the economy because this disease often evolves over a long period of time. In contrast, deaths due to accidents, homicides, and even cardiovascular disease may be heavily influenced by short-run macroeconomic fluctuations.

This paper examines one particularly tragic aspect of the mortality crisis in the former 
Soviet countries: the tremendous increase in suicide rates, especially among middle-aged men, in the 'mortality belt' countries identified above. These suicides appear to be highly sensitive to the state of the economy and account for as much as 16 percent of the total increase in deaths in the early 1990s. The highest male suicide rates in the world are recorded in Lithuania - reaching a rate of 79.3 suicides per 100,000 population in 1996 - although the suicide rates in Russia and its western neighbors are close behind. The male suicide rates in these countries far exceed those of other countries characterized by high suicide rates; in Japan and Finland, for example, the male suicide rate was 24.3 and 38.7 per 100,000, respectively, in 1996 (WHO 1999).

This paper uses data from 22 transition economies to document these mortality trends and test the correlation between suicide rates and economic and social variables such as unemployment, income, and divorce rates. The paper also explores the possibility that the mortality crisis had a 'feedback' effect on suicide rates, with the loss of a close acquaintance - or declining life expectancy itself - in turn contributing to rising suicide rates.

\section{THE MORTALITY CRISIS AND SUICIDE IN THE FORMER SOVIET UNION：AN OVERVIEW}

In most industrialized countries life expectancy evolves slowly over time and is relatively insensitive to short-term economic fluctuations. This is evident in Figure 1a, which shows male life expectancy at birth in Japan, Italy, and many of the 'mortality belt' countries since 1958. Despite the many business cycles and social changes marking these decades, life expectancy advanced systematically in Italy and Japan. In contrast, male life expectancy in Russia fluctuates dramatically over relatively short periods of time. ${ }^{1}$ After years of deterioration, male life expectancy increased sharply in 1986-87 during Gorbachev's anti-alcohol campaign and is

\footnotetext{
${ }^{1}$ Female and male life expectancy follow similar patterns in Russia, but the level of life expectancy is higher and the fluctuations are less dramatic for women. The Russian mortality data appear to be reliable (Leon et al 1997; Wasserman and Värnik 1998).
} 
widely attributed to reduced alcohol consumption, although the unprecedented social and political changes initiated in those years may have favorably affected mortality as well. Life expectancy declined dramatically in 1992, the year that Russia dismantled its system of central planning and experienced near-hyperinflation, and the decline accelerated through 1994 before recovering substantially in subsequent years. Further underscoring the sensitivity of life expectancy to economic conditions, both male and female life expectancy declined in 1999 following the August 1998 financial crisis. Life expectancy in the western countries of the former Soviet Union (FSU) is also sensitive to changing economic and social conditions and follows a remarkably similar pattern to that of Russia. Life expectancy fell noticeably in many of the Central Asian republics in the early 1990s, but the declines are less dramatic than those that occurred in Russia (not shown).

Remarkably, despite massive declines in per capita income, rising unemployment, and a wide range of reform experiences, none of the East European countries experienced a prolonged or steep decline in life expectancy in the 1990s; the most successful economic reformers - the Czech Republic, Poland, and Hungary - registered near-continual increases in life expectancy since the start of their reforms (Figure 1b). This differs not only with the neighboring 'mortality belt' countries, but also with the experience of the previous decades in which life expectancy stagnated in a pattern similar to that of the USSR. Life expectancy fell in Romania (and Bulgaria), but the declines are small relative to those that occurred in Russia.

Men in their prime working ages have disproportionately borne the mortality burden in Russia and its western neighbors; the typically more vulnerable groups - children and the elderly - largely escaped the demographic catastrophe of the 1990s (Shkolnikov et al 1998). The increase in mortality rates is largely due to increased death from circulatory diseases (e.g. heart attack and stroke) and from accidents and injuries. Within the working age population, the latter 
category of deaths accounts for 44 percent of the mortality increase in Russia and 56 percent of the increased deaths in Belarus (Table 1).

Suicide rates, in turn, comprise an astonishingly high share of the increase in deaths due to accidents and injuries and of deaths overall: suicide alone accounted for over 16 percent of the increased mortality among the working age population in Belarus from 1990 to 1997, and nearly 13 percent of the increased mortality in Lithuania between 1990 and 1995 (Table 1). The contribution is surely higher for working age men, but disaggregated figures for most countries are unavailable.

Figure 2a illustrates the rise in male suicide rates in the 'mortality belt' in the early 1990s (female suicide rates are much lower, as in most countries, and are not shown). The increase in suicide rates in the Baltics is surprising not only because the economic reforms were relatively successful in those countries, but also because in 1991 the Baltics achieved independence from the USSR, long-sought after their forcible incorporation into the Soviet Union in 1940. The euphoria that followed might have buffered the economic changes and led to declining suicide rates, but instead the opposite occurred and by the mid-1990s Lithuania, followed closely by its neighbors, registered the highest male suicide rates in the world. In contrast, male suicide rates in the Central Asian republics and the Caucuses fluctuated little in the 1990s.

Male and female suicide rates in most of Eastern Europe also remained relatively stable throughout the 1990s. Male suicide rates increased slightly in Poland and Romania between 1990 and 1993 (Figure 2b), while a slight downward trend occurred in Slovenia and the Czech Republic. The male suicide rate fell substantially in Hungary throughout the period; prior to this decline, the male suicide rate in Hungary had been among the highest in the world.

Older men have been disproportionately affected by the suicide epidemic; in Russia in 1994, for example, the suicide rate among men age 50-54 reached 139.6 per 100,000 . In 
Lithuania in 1996, male suicides reached the astonishing rate of 171 per 100,000 in the $45-54$ age group. This pattern of suicide rates is unusual - in many countries the highest suicide rates occur among the elderly (as in Japan) or among youth (as in the U.K.) - and suggests a link with recent changes in the labor market in these countries, such as declining real wages, increased unemployment, and the devaluation of human capital for older workers.

\section{AN ECONOMIC APPROACH TO UNDERSTANDING SUICIDE}

Before turning to the evidence on the sources of rising suicide rates, it is useful to consider the factors that may induce an individual to take his own life. The approach taken here is primarily an economic approach although sociological theory regarding the causes of suicide is incorporated as well. This is not to deny that many non-economic factors influence such a decision, but at the margin an individual's economic and social circumstances likely play an important role in suicidal behavior.

In the tradition of the human capital approach, the economic approach to mortality seeks to identify the economic changes that induce individuals to alter their behavior in ways that influence their health (Becker 1964; Grossman 1972). The individual's stock of health is viewed as a form of human capital: the individual inherits an initial stock of health and invests in health over the lifetime to produce a stock of health which depreciates with age. The decision to invest in health is affected by income, the cost of health inputs, the return to investment in human capital, and the time horizon over which one can expect to recoup the investment.

Working within this framework, Hamermesh and Soss (1974) formulated an economic model of suicide that models the individual as a rational, optimizing agent who takes his own life when the total discounted lifetime utility remaining to him reaches zero. For an individual with permanent income $Y$, the present value of lifetime expected utility at age $a$ is expressed as: 


$$
Z(a, Y)=\int_{a}^{\omega} e^{-r(m-a)} U_{m} P(m) d m
$$

where $\omega$ is the highest attainable age, $\mathrm{r}$ is the individual's discount rate, and $\mathrm{P}(m)$ is the probability of surviving to age $m$, given that one has reached age $a$. Utility, $U_{m}$, depends on consumption which in turn is a function of age and income. The theory predicts that suicide rates increase with age and decrease with income, and empirically the authors show that these predictions hold over time and across U.S. states. ${ }^{2}$

Additionally, notice that the present value of lifetime expected utility depends as well on the probability of surviving to reach a given age: the higher the probability of survival, the greater the lifetime expected utility and the less likely that this utility reaches zero before the individual dies of other causes. In other words, remaining life expectancy may itself influence the decision to take one's own life.

Declining life expectancy can thus create a vicious circle: falling life expectancy may lead to an increase in suicide rates, which in turn exacerbates the decline in life expectancy, leading to increased suicide rates. As an aside, note that this 'vicious circle' effect may be true of other causes of death, because as life expectancy declines it becomes less worthwhile to the individual to invest in health: there is less (expected) time to recoup the investment. Similarly, the process likely works in reverse to create a virtuous circle of rising life expectancy in which, for example, an increase in life expectancy due to medical advances leads to further increases in

${ }^{2}$ Dixit and Pindyck (1994) point out that an 'option value' of waiting could be incorporated into this model: because suicide is an irreversible act and expected future utility is uncertain, there is a high option value to postponing such a decision. 
life expectancy as individuals increase their investment in health in response. ${ }^{3}$

In contrast to the economic approach, sociologists emphasize the social determinants of suicide. The seminal work of Durkheim (1897) argued that suicide is related not only to individual traits and circumstances but also to the characteristics of the society in which one lives. In Durkheim's view, the disintegration of society - as manifested in changing family structure, weakening of religious ties, even political instability - results in an increase in the suicide rate within a community. Durkheim's model provided the foundation for much of the subsequent research on suicide by sociologists.

These theories suggest a number of variables that may explain the diversity of suicide rates across the formerly socialist countries. The economic approach predicts that suicide rates will rise with age and unemployment (as an indicator of a transitory shock to income), and will be negatively related to income and survival probabilities. The sociological approach suggests that suicide rates will be positively related to measures of social disintegration such as divorce and crime rates. In addition, rising suicide rates are likely related to the increased stress that accompanied the collapse of the socialist system: while the systemic change created vastly increased opportunities for individuals, at the same time it destroyed the economic security to which they had become accustomed and which had existed in most countries for decades. It is impossible to measure the stress of the transition, but measures of alcohol consumption may capture some of this effect.

\section{Cross-COUnTry EVIDENCE}

The primary empirical strategy is to estimate fixed effects regressions of the following

\footnotetext{
${ }^{3}$ For this feedback effect to operate, individuals must be aware of changes in life expectancy and incorporate these changes into their own subjective time horizons. For evidence that this is true in the U.S., see Hamermesh (1985).
} 
form, using data for 22 transition economies for the 1988-1998 period: ${ }^{4}$

$$
S_{j t}=\alpha_{j}+\beta_{t}+E_{j t} \gamma+X_{j t} \delta+L_{j t} \phi+\varepsilon_{j t}
$$

where $j$ and $t$ index country and years, respectively; $\mathrm{S}_{\mathrm{jt}}$ is the age-standardized death rate from suicide in the 0-64 age group for men or women (in logs); $\mathrm{E}_{\mathrm{jt}}$ are measures of economic conditions such as GNP per capita and employment; $\mathrm{X}_{\mathrm{jt}}$ is a vector of regressors capturing social correlates of suicide rates, such as divorce rates and alcohol consumption; $\mathrm{L}_{\mathrm{jt}}$ is remaining life expectancy at age 65 , the measure of time horizons; and $\epsilon_{\mathrm{jt}}$ is the error term. ${ }^{5}$ The term $\alpha_{\mathrm{j}}$ controls for factors influencing the level of suicide rates that are invariant over time within each country, while $\beta_{\mathrm{t}}$ controls for region-wide time trends. ${ }^{6}$

The results of these regressions are reported in Table 2. The first three columns indicate that GNP per capita and the employment to population ratio are negatively correlated with male suicide rates and are highly statistically significant. An increase in GNP per capita of \$100 lowers the predicted male suicide rate by $.14-.20$ percent, while a one percentage point increase in the employment to population ratio reduces the male suicide rate by about 3 percent. This is similar to the U.S., where suicide rates also rise during recessions: for each one percentage point increase in a state's unemployment rate, the suicide rate is predicted to rise by about 1.3 percent (Ruhm 2000).

\footnotetext{
${ }^{4}$ The countries are: Armenia, Azerbaijan, Belarus, Bulgaria, Czech and Slovak Republics, Estonia, Georgia, Hungary, Kazakhstan, Kyrgyzstan, Latvia, Lithuania, Moldova, Poland, Romania, Russia, Slovenia, Tadjikistan, Turkmenistan, Ukraine and Uzbekistan. The panel is unbalanced because data are missing for some countries in some years.

${ }^{5}$ The suicide rate for the age 0-64 age group is used as the dependent variable instead of the rate for all age groups because the latter measure mechanically affects remaining life expectancy at age 65 .

${ }^{6}$ Note that GNP per capita, employment, crime rates, and alcohol consumption are likely underestimated due to measurement problems and reporting difficulties. Because measurement error results in attenuation bias and this effect is exacerbated in fixed effects regressions, the regression estimates are biased toward finding no effects for most regressors.
} 
Divorce rates are also a significant predictor of male suicide rates; this parallels results found in the U.S. for all adults (Cutler et al 2000) and coincides with individual-level studies indicating that divorced men are more prone to commit suicide than married or single men (Kposowa 2000). However, this correlation could also indicate that an omitted third variable such as stress - resulted in both rising divorce rates and rising suicide rates. Unfortunately it is impossible to distinguish these two hypotheses with the available data.

Alcohol consumption per capita is positively related to male suicide rates, as might be expected, but the effect is imprecisely estimated; in part this likely stems from the difficulty of measuring alcohol consumption within and across countries. Somewhat surprisingly, the crime rate is uncorrelated with suicide rates in all regressions, even though this variable might be considered a reasonable proxy for the integration or disintegration within a society. While its statistical insignificance may be due to measurement error or to collinearity with other regressors, even as the sole regressor it remains statistically insignificant (results not shown).

The second column adds male life expectancy at age 65 as a regressor. It is negatively related to the male suicide rate, as predicted, and is highly statistically significant. As discussed above, this may indicate that as an individual's remaining time horizon - and remaining lifetime expected utility - fall, suicide rates rise, in turn creating a 'feedback' effect to falling life expectancy. An alternative interpretation is that this variable simply reflects declining male life expectancy overall (the correlation between male life expectancy at birth and at age 65 is .70) and that the positive coefficient indicates that as individuals increasingly lose family members and friends during a time of falling life expectancy, they are more likely to take their own life. A third interpretation is that an omitted third variable correlated with both the suicide rate and life expectancy at 65 is driving both.

As a test to distinguish these hypotheses, the third column replaces male life expectancy 
at age 65 with female life expectancy at 65: if the increase in male suicide rates is due to personal loss rather than to diminished time horizons - or if it is due simply to the stress of the transition that led to declining life expectancy overall - then female life expectancy should also be significantly correlated with the male suicide rate; this is especially true because male and female life expectancy at 65 are highly correlated (correlation $=.71$ ). This is not the case, however: male suicide rates are unrelated to falling life expectancy for women. This suggests that the time horizon interpretation of the remaining life expectancy variable may be more appropriate.

Turning to the results for women, the female suicide rate is relatively insensitive to economic conditions: the coefficient on GNP per capita is statistically insignificant, while that on the employment to population ratio is significant at only the 7 percent level in two of the three specifications. The finding that men are more sensitive to changes in income than women echoes a similar finding for Taiwan (Chuang and Huang 1997) and may reflect that women's nonmarket work is valued more highly than men's in these societies, which provides women with greater protection from macroeconomic instability than men whose ability to produce in the market is valued more highly.

The female suicide rate is strongly associated with the divorce rate, as it was for men, but in contrast to men it is also strongly associated with alcohol consumption. Because the alcohol consumption data are for the population rather than male and female alcohol consumption separately, and because most alcohol is consumed by males in these countries, this result may indicate that female suicide rates are positively related to male alcohol consumption. Finally, the female suicide rate is negatively and significantly related to male life expectancy at age 65 , but is uncorrelated with female life expectancy at age 65. The latter result is surprising and may indicate that declining life expectancy for women has less of an impact on future consumption and utility than for men because women contribute less to household income than do men. 
A final factor to consider in understanding suicides in the former Soviet Union is the changing returns to human capital and rising inequality experienced in many countries in recent years. The suicide epidemic most affected men in their prime working ages, and this same group experienced a substantial loss in real and relative wages since the beginning of reforms in many countries. In Russia, for example, men with several decades of labor market experience - men who would be at their peak earning years in most countries - earned lower wages on average than did new entrants to the labor market in 1994 (Brainerd 1998). This devaluation of the human capital of older workers is likely related to the suicide epidemic among this age group, but little data on labor market outcomes of older men across FSU countries other than Russia exist to confirm such a hypothesis statistically.

\section{CONCLUDING REMARKS}

The suicide epidemic in the former Soviet Union has led to thousands of avoidable deaths, each one representing a human tragedy in its own right, and to a region now characterized by the highest suicide rates in the world. The cross-country evidence examined here suggests that male suicide rates are strongly related to the state of the macroeconomy; and while all formerly socialist countries experienced rising unemployment and falling per capita income in the early 1990s, the macroeconomic decline in the 'mortality belt' was steeper and more prolonged than that of Eastern Europe, and likely accounts for the higher suicide rates in the former Soviet countries. More generally, the finding that there is a statistically significant link between this cause of death and macroeconomic conditions provides further support to the emerging consensus that macroeconomics and health are strongly related. 


\section{ACKNOWLEDGMENTS}

Alberto Chong, Daniel Hamermesh and Robert Jensen provided helpful comments on this paper. The financial support of the German Marshall Fund of the United States is gratefully acknowledged.

\section{REFERENCES}

Becker, G. 1964. Human capital: a theoretical and empirical analysis, with special reference to education. New York: National Bureau of Economic Research.

Brainerd, E. 1998. Winners and losers in Russia's Economic Transition. American Economic Review, $88,1094-1116$.

Chuang, H., Huang, W. 1997. Economic and social correlates of regional suicide rates: A pooled crosssection and time-series analysis. Journal of Socio-Economics 26, 277-289.

Cutler, D., Glaeser, E., Norberg, K. 2000. Explaining the rise in youth suicide. NBER Working Paper No. 7713.

Dixit, A., Pindyck, R. 1994. Investment under uncertainty. Princeton, NJ: Princeton University Press.

Durkheim, E. 1957. Le suicide. Trans. J. Spaulding and G. Simpson. New York: Free Press.

Grossman, M. 1972. On the concept of health capital and the demand for health. Journal of Political Economy 10, 223-255.

Hamermesh, D. 1985. Expectations, life expectancy, and economic behavior. Quarterly Journal of Economics 100, 389-408.

Hamermesh, D., Soss, N. 1974. An economic theory of suicide. Journal of Political Economy 82, 83-98.

Kposowa, A. 2000. Marital status and suicide in the National Longitudinal Mortality Study. Journal of Epidemiology \& Community Health. 54, 254-261.

Leon, D. et al. 1997. Huge variation in Russian mortality rates in 1984-1994. Artefact, alcohol or what? Lancet 350, 383-388.

Ruhm, C. 2000. Are recessions good for your health? Quarterly Journal of Economics CXV, 617-650.

Shkolnikov, V., Cornia, G., Leon, D., Meslé, F. 1998. Causes of the Russian mortality crisis: evidence and interpretations. World Development 26, 1995-2011.

Wasserman, D., Värnik, A. 1998. Reliability of statistics on violent death and suicide in the former USSR, 1970 - 1990. Acta Psychiatrica Scandinavica 98 (Suppl. 394), 34-41.

World Health Organization. 1999. Figures \& facts about suicide. Geneva. 
Figure 1. Trends in male life expectancy at birth, 1958 - 1999

(a)
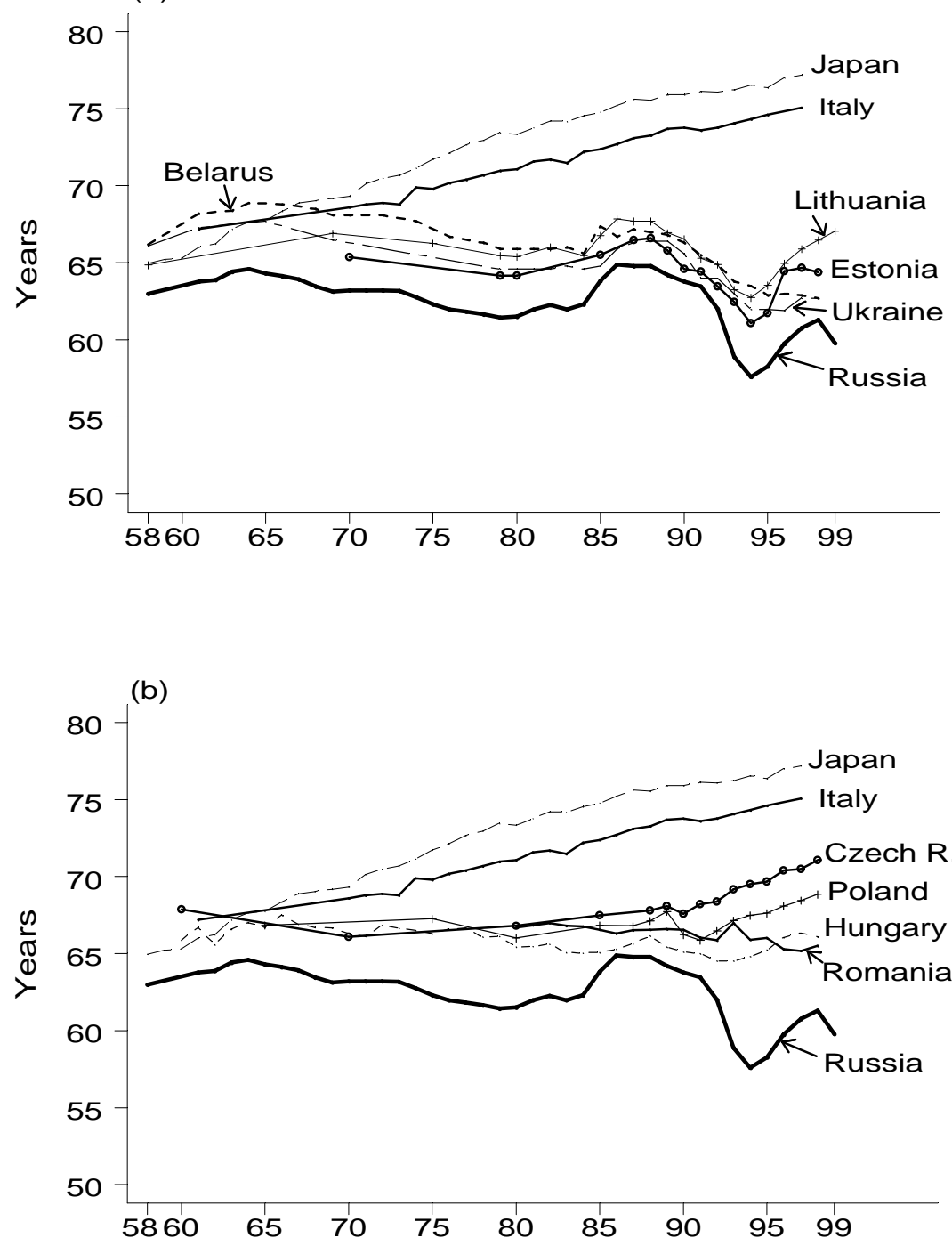
Table 2. Percentage increase in deaths due to selected causes, $1990-1995^{\mathrm{a}}$

\begin{tabular}{cccc}
\hline & \multicolumn{2}{c}{ Percentage increase in all deaths due to: } & \\
& Circulatory disease & Accidents and injuries & Of which, suicide \\
\hline Russia, all pop. & $48.9 \%$ & 26.0 & 3.5 \\
Working age pop. ${ }^{\mathrm{b}}$ & 30.6 & 44.4 & 6.5 \\
Belarus, all pop. & 48.6 & 20.3 & 5.4 \\
Working age pop. ${ }^{\mathrm{b}}$ & 25.8 & 55.9 & 16.4 \\
Ukraine, all pop. & 71.4 & 16.3 & 2.4 \\
Working age pop. ${ }^{\mathrm{b}}$ & 32.8 & 33.2 & $\mathrm{na}$ \\
Estonia, all pop. & 11.9 & 41.7 & 8.0 \\
Latvia, all pop. & 42.7 & 27.4 & 6.0 \\
Lithuania, all pop. & 23.8 & 37.0 & 12.9 \\
\hline
\end{tabular}

${ }^{a}$ Calculated by dividing the change in each cause of death by the change in all deaths from 1990-95 (1990-94 for Russia; 1990-97 for Belarus). For example, in Russia the death rate increased from 1116.7 to 1566.1 per 100,000 population, an increase of 449.4; deaths due to circulatory disease increased from 617.4 to 837.3 , an increase of 219.9. The increase in deaths due to circulatory diseases is then (219.9/449.4), or 48.9 percent.

${ }^{\mathrm{b}}$ The working age population in all countries is age 16 to 59 for men, 16 to 54 for women.

Sources: Demographic Yearbook of Russia 1997; Statistical Yearbook of the Republic of Belarus 1998; Statistical Yearbook for Ukraine 1998; Demographic Data Collection of Estonia, Latvia and Lithuania 1996. 
Figure 2. Male suicide rates in the formerly socialist countries (standardized)

(a)

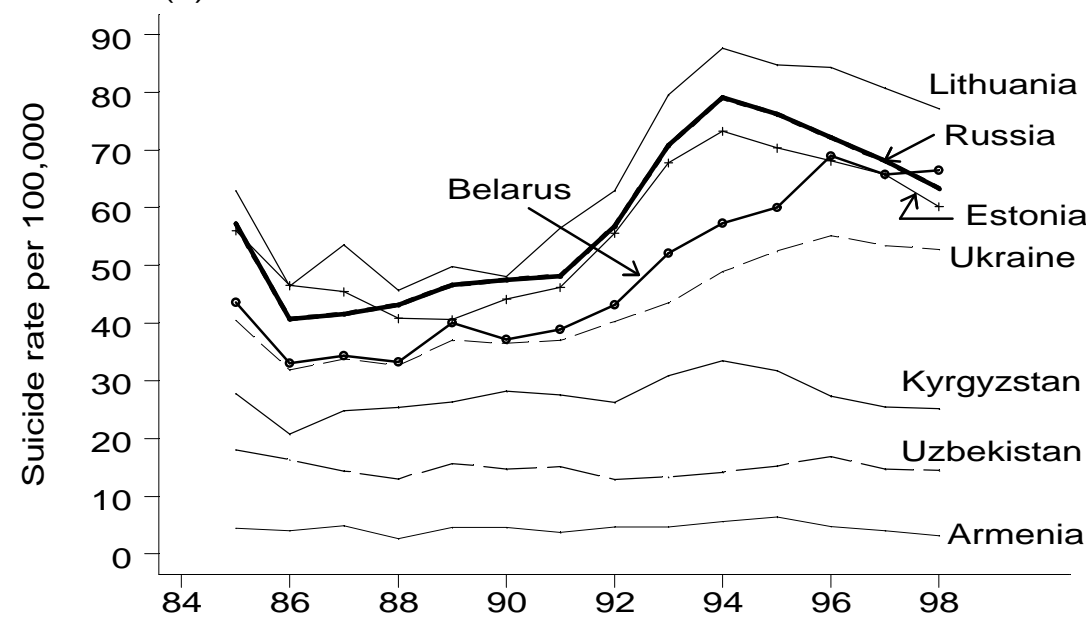

(b)

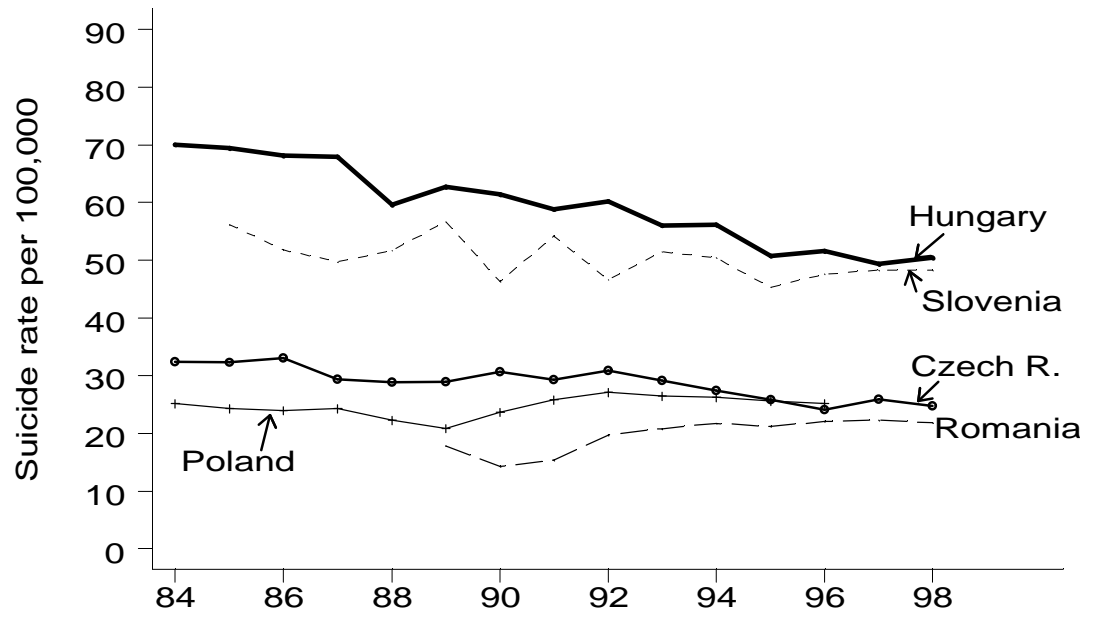


Table 2. Fixed effects regressions, 1988 - 1998

(standard errors in parentheses)

Dependent variable: Standardized mortality rate, suicides per 100,000 age 0 - 64 (in logs)

\begin{tabular}{|c|c|c|c|c|c|c|}
\hline & & \multicolumn{2}{|c|}{ Men } & \multicolumn{3}{|c|}{ Women } \\
\hline $\begin{array}{l}\text { GNP per capita, 100s } \\
\text { of } 1995 \text { U.S. dollars }\end{array}$ & $\begin{array}{l}-.020 * * * \\
(.006)\end{array}$ & $\begin{array}{l}-.014 * * \\
(.006)\end{array}$ & $\begin{array}{l}-.020 * * * \\
(.006)\end{array}$ & $\begin{array}{l}-.011 \\
(.007)\end{array}$ & $\begin{array}{l}-.007 \\
(.007)\end{array}$ & $\begin{array}{l}-.012 \\
(.007)\end{array}$ \\
\hline $\begin{array}{l}\text { Employment/population } \\
\text { ratio }\end{array}$ & $\begin{array}{l}-.032 * * * \\
(.011)\end{array}$ & $\begin{array}{c}-.025 * * \\
(.011)\end{array}$ & $\begin{array}{l}-.032 * * * \\
(.011)\end{array}$ & $\begin{array}{l}-.026^{*} \\
(.014)\end{array}$ & $\begin{array}{l}-.021 \\
(.014)\end{array}$ & $\begin{array}{l}-.026^{*} \\
(.014)\end{array}$ \\
\hline $\begin{array}{l}\text { Divorce rate per } 1000 \\
\text { population }\end{array}$ & $\begin{array}{l}.174 * * * \\
(.048)\end{array}$ & $\begin{array}{l}.134 * * * \\
(.047)\end{array}$ & $\begin{array}{l}.174 * * * \\
(.048)\end{array}$ & $\begin{array}{l}.181 * * * \\
(.059)\end{array}$ & $\begin{array}{l}.150 * * * \\
(.060)\end{array}$ & $\begin{array}{l}.183 * * * \\
(.059)\end{array}$ \\
\hline $\begin{array}{l}\text { Alcohol consumption } \\
\text { per capita, liters of } \\
\text { pure alcohol }\end{array}$ & $\begin{array}{l}.025 \\
(.016)\end{array}$ & $\begin{array}{l}.029 * \\
(.015)\end{array}$ & $\begin{array}{l}.025 \\
(.016)\end{array}$ & $\begin{array}{l}.048 * * * \\
(.019)\end{array}$ & $\begin{array}{l}.051 * * * \\
(.019)\end{array}$ & $\begin{array}{l}.048 * * \\
(.019)\end{array}$ \\
\hline $\begin{array}{l}\text { Crime rate per } 1000 \\
\text { population }\end{array}$ & $\begin{array}{l}.0004 \\
(.004)\end{array}$ & $\begin{array}{l}.007 \\
(.004)\end{array}$ & $\begin{array}{l}.0007 \\
(.006)\end{array}$ & $\begin{array}{l}.002 \\
(.005)\end{array}$ & $\begin{array}{l}.007 \\
(.006)\end{array}$ & $\begin{array}{c}.001 \\
(.006)\end{array}$ \\
\hline $\begin{array}{l}\text { Life expectancy at age } \\
\text { 65: Men } \\
\text { Women }\end{array}$ & & $\begin{array}{l}-.156 * * * \\
(.044)\end{array}$ & $\begin{array}{l}-.004 \\
(.038)\end{array}$ & & $\begin{array}{l}-.117 * * \\
(.056)\end{array}$ & $\begin{array}{l}.016 \\
(.047)\end{array}$ \\
\hline Adjusted $\mathrm{R}^{2}$ & .949 & .953 & .948 & .895 & .898 & .895 \\
\hline
\end{tabular}

$* * *$ Statistically significant at the $1 \%$ level; **5\% level; *10\% level. Sample size is 177 for all regressions.

Data sources: Suicide rates and life expectancy: WHO Health for All database, June 2000 version; GNP per capita: World Bank, 2000 World Development Indicators; employment, population, divorce rates, crime rates: Official Statistics of the Countries of the Commonwealth of Independent States 1999 and national statistical yearbooks; alcohol consumption: WHO Health for All database and national statistical yearbooks. 


\section{IZA Discussion Papers}

No Author(s)

151 M. Ward

152 J. J. Dolado

F. Felgueroso

J. F. Jimeno

153 A. S. Kalwij

M. Gregory

154 M. Gerfin

M. Lechner

155 J. Hansen

156 C. Dustmann

F. Fabbri

157 P. Apps

R. Rees

158 A. Björklund

T. Eriksson

M. Jäntti

O. Raaum

E. Österbacka

159 P.- J. Jost

M. Kräkel

160 M. Lofstrom

161

V. Gimpelson

D. Treisman

G. Monusova

162 C. Dustmann

M. E. Rochina-

Barrachina

163 R. A. Hart

Y. Ma

164 M. A. Shields

S. Wheatley Price

165
Titel

Area

Date

Gender, Salary and Promotion in the Academic Profession

The Role of the Minimum Wage in the Welfare 3 State: An Appraisal

5

$5 / 00$

$5 / 00$

Overtime Hours in Great Britain over the Period 3

1975-1999: A Panel Data Analysis

Microeconometric Evaluation of the Active Labour 6

Market Policy in Switzerland

The Duration of Immigrants' Unemployment Spells: $\quad 1 / 3$

Evidence from Sweden

Language Proficiency and Labour Market Per- 1

formance of Immigrants in the UK

Household Production, Full Consumption and

7

the Costs of Children

Brother Correlations in Earnings in Denmark, 5

Finland, Norway and Sweden Compared to the United States

Preemptive Behavior in Sequential Tournaments

5

$5 / 00$

A Comparison of the Human Capital and Signaling Models: The Case of the Self-Employed and the Increase in the Schooling Premium in the 1980's

Public Employment and Redistributive Politics: 4 Evidence from Russia's Regions

Selection Correction in Panel Data Models: An 6 Application to Labour Supply and Wages

$6 / 00$

Why do Firms Pay an Overtime Premium?

5

$6 / 00$

Racial Harassment, Job Satisfaction and Intentions

5

$6 / 00$

to Quit: Evidence from the British Nursing Profession

Immigration in a High Unemployment Economy: 1 The Recent Danish Experience 
B. Nolan

Earnings Inequality, Returns to Education and 5

Immigration Policy in Integrated National

$7 / 00$

171 C. Dustmann Economies

Wages and the Demand for Health - A Life Cycle

Analysis

172 D. Card

Reforming the Financial Incentives of the Welfare System 

J. M. Abowd
F. Kramarz
D. N. Margolis
T. Philippon

204

G. S. Epstein

A. L. Booth

M. Francesconi

J. Frank

C. M. Schmidt

R. Baltussen

R. Sauerborn

J. Hartog

R. Winkelmann

209

M. Barbie

M. Hagedorn

A. Kaul

210 T. J. Dohmen

211
A. van Soest
M. Das
X. Gong

212 X. Gong

A. van Soest

P. Zhang

213 X. Gong

A. van Soest

E. Villagomez

$214 \quad$ X. Gong

A. van Soest

215 J. Ermisch

M. Francesconi

216 F. Büchel
The Tail of Two Countries: Minimum Wages and 5

Employment in France and the United States
$9 / 00$

Labor Market Interactions Between Legal and

1

$10 / 00$

Ilegal Immigrants

Temporary Jobs: Stepping Stones or Dead Ends? 1

$10 / 00$

The Evaluation of Community-Based Interventions: Group-Randomization, Limits and

6

$10 / 00$ Alternatives

Arbeitsmarktpolitische Maßnahmen und ihre

Dutch Migrants in New Zealand:

$10 / 00$

Did they Fare Well?

Dynamic Effciency and Pareto Optimality in a

3

$10 / 00$

Stochastic OLG Model with Production and Social

Security

Housing, Mobility and Unemployment

$11 / 00$

A Structural Labour Supply Model with

5

$11 / 00$

Nonparametric Preferences

Sexual Bias and Household Consumption: A

5

Semiparametric Analysis of Engel Curves in Rural China

Mobility in the Urban Labor Market: A Panel Data 1 Analysis for Mexico

Family Structure and Female Labour Supply in

5

$11 / 00$ Mexico City

The Effect of Parents' Employment on Children's

5

$11 / 00$ 

when? and Earnings: An Empirical Study for Portugal 

1969-95 the 1990s 